\title{
Fogacin, a Novel Cyclic Octaketide Produced by Streptomyces Strain Tü $6319^{\dagger}$
}

\author{
Markus Radzom, Axel Zeeck, Noémi Antal, Hans-Peter Fiedler
}

Received: February 14, 2006 / Accepted: May 15, 2006

(C) Japan Antibiotics Research Association

\begin{abstract}
A new octaketide named fogacin (1) was isolated from Streptomyces sp. (strain Tü 6319). Furthermore two shunt metabolites, SEK4b (2) and anhydroSEK4b (3), were detected and identified as nonenzymatically cyclized products of polyketide intermediates built during the biosynthesis of actinorhodin. SEK4b (2) as well as anhydroSEK4b (3) were previously described as metabolites of genetically engineered strains.
\end{abstract}

Keywords polyketides, biosynthesis, shunt metabolites, SEK4b, HPLC screening

Freshly isolated strains from soils collected at various sites in Romania were included in our HPLC-diode array screening program to detect novel secondary metabolites. Strain Tü 6319 which was isolated from an industrial contaminated soil near Fogaras, Romania, drew our attention because of its characteristic metabolite pattern, which appears analyzing the culture filtrate extract. Three of the metabolites were identified by means of our HPLCUV-Vis database [2] as SEK4b (2) [3], and germicidins A and B [4], respectively. Two further metabolites did not correspond to any of the 834 reference compounds stored in our database. One of them was identified as anhydroSEK4b (3) [5], the second was named fogacin (1).

Strain Tü 6319 was examined for a number of key properties known to be of value in streptomycete systematics. The presence of LL-diaminopimelic acid in the peptidoglycan together with its colonial characteristics allowed its assignment to the genus Streptomyces. Strain Tü 6319 shared a high 16S rRNA gene sequence with the closely related type strains Streptomyces coelescens DSM 40421, S. violaceolatus DSM 40438 and S. violaceoruber DSM 40049.

Batch fermentation of strain Tü 6319 was carried out in 10-liter stirred tank fermenters (New Brunswick) in a medium that consisted of oat meal $2.0 \%$ in tap water $(\mathrm{pH}$ 7.3). The fermentation was conducted at $27^{\circ} \mathrm{C}$ for 168 hours with an aeration rate of $0.5 \mathrm{v} / \mathrm{v} / \mathrm{m}$ and agitation of $200 \mathrm{rpm}$. Addition of $3 \%$ DMSO to the medium increased the production of 1 by $33 \%$, reaching a maximum value of $10 \mathrm{mg} /$ liter after 168 hours. Compound $\mathbf{1}$ was isolated from the culture filtrate (13 liters), loaded onto an Amberlite XAD-16 column $(8 \times 40 \mathrm{~cm})$ and eluted by increasing concentrations of $\mathrm{MeOH}$. The $40 \% \mathrm{MeOH}$ fraction that contained 1 was concentrated in vacuo, adjusted to $\mathrm{pH} 2$, and extracted with ethyl acetate. The raw material was separated on a LiChroprep Diol column $(2.6 \times 40 \mathrm{~cm}$; Merck) applying a linear gradient $\mathrm{CH}_{2} \mathrm{Cl}_{2}$ to a content of $5 \% \mathrm{MeOH}$ within 3 hours at a flow rate of $5 \mathrm{ml} /$ minute. A further metabolite (3) was separated from 1, and both compounds were purified by subsequent column chromatography on Sephadex LH-20 and Fractogel TSK HW-40 (each column $1.5 \times 90 \mathrm{~cm}$, flow rate $15 \mathrm{ml} /$ hour) using $\mathrm{MeOH}$ as eluent. Pure $\mathbf{1}$ was obtained in an amount of $8 \mathrm{mg}$.

The antimicrobial activities of fogacin (1) and anhydro SEK4b (3) were examined by an agar plate diffusion assays. Compound $\mathbf{3}$ revealed a moderate inhibitory activity against Bacillus subtilis DSM 10 and
A. Zeeck (Corresponding author), M. Radzom: Institut für Organische und Bioorganische Chemie, Universität Göttingen, Tammannstr. 2, D-37077 Göttingen, Germany,

E-mail: azeeck@gwdg.de
H.-P. Fiedler, N. Antal: Mikrobiologisches Institut, Universität Tübingen, Auf der Morgenstelle 28, D-72076 Tübingen, Germany †Art. No. 36 in 'Biosynthetic Capacities of Actinomycetes'. Art. No. 35: See ref. 1. 


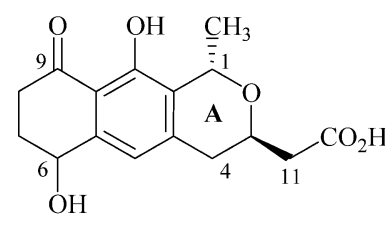

1

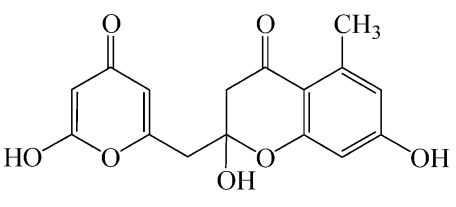

2

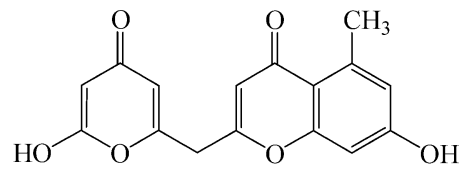

3

Fig. 1 Structures of fogacin (1) (relative stereochemistry of ring A shown), SEK4b (2) and anhydroSEK4b (3).

S. viridochromogenes Tü 57, showing inhibition zones of $11 \mathrm{~mm}$ and $16 \mathrm{~mm}$, respectively, at concentrations of $1.0 \mathrm{mg} / \mathrm{ml}$. Gram-negative bacteria, yeasts and filamentous fungi were not sensitive to $\mathbf{1}$ and $\mathbf{3}$.

Fogacin (1) was isolated as colourless solid. The ESI-MS (positive mode) displayed a peak at $m / z 307(\mathrm{M}+\mathrm{H})^{+}$, high resolution of it leads to the molecular formula $\mathrm{C}_{16} \mathrm{H}_{18} \mathrm{O}_{6}$. The ${ }^{13} \mathrm{C}$ NMR spectrum of $\mathbf{1}$ shows 16 signals among them a carbonyl group $\left(\delta_{\mathrm{C}} 206.1\right)$ and a carboxylic acid $\left(\delta_{\mathrm{C}}\right.$ $176.0)$ besides six aromatic carbons. In the region of aliphatic carbon atoms three oxygen bound methine, four methylene groups and one methyl group can be observed. In accordance the ${ }^{1} \mathrm{H}$-NMR spectrum of $\mathbf{1}$ shows besides four diastereotopic methylene and three highly coupled methine signals one methyl group as doublet and only one aromatic proton as singlet. ${ }^{1} \mathrm{H}-\mathrm{COSY}$ and $\mathrm{HMBC}$ spectra as well as the values of the coupling constants of $\mathbf{1}$ prove the direct vicinity of $6-\mathrm{H}, 7-\mathrm{H}_{\mathrm{a}, \mathrm{b}}$ and $8-\mathrm{H}_{\mathrm{a}, \mathrm{b}}$ with a quasi equatorial position of $6-\mathrm{OH}$. The connection between the rings is revealed by HMBC-couplings shown in Fig. 2. Additionally an 1D-NOE experiment exhibits a strong coupling between $3-\mathrm{H}$ and the methyl group, while no coupling can be observed between $3-\mathrm{H}$ and $1-\mathrm{H}$. Furthermore, 1-H shows no coupling to any proton except that of the methyl group. Thus, the relative stereochemistry of ring A of $\mathbf{1}$ is assigned to be trans. Compound $\mathbf{1}$ represents the framework of one half of actinorhodin (4), but differs in its structure from all known intermediates which were identified along the biosynthetic route of 4 [3].

Octaketides like $\mathbf{2}$ and $\mathbf{3}$ are known shunt metabolites of the actinorhodin biosynthetic pathway (Fig. 3) which are often found in experiments with streptomycetes mutants bearing manipulations in the cyclase functions of type II polyketide synthases (PKS) [6, 7] and are under ongoing investigations [8]. In these experiments 2 and 3 turned out to be important key metabolites for the elucidation of the biosynthetic pathway of 4 . They are built by a so called 'minimal PKS' and products of subsequent nonenzymatic cyclization of the linear polyketide. In contrast, substance $\mathbf{1}$ has to be a product of stereospecific cyclization and miscellaneous tailoring steps (e.g. reduction and hydroxylation) like actinorhodin and other aromatic

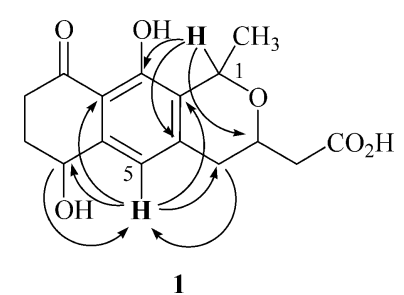

Fig. 2 Important HMBC-correlations of fogacin (1): ${ }^{3} J_{C, H}$ couplings reveal the regiochemistry of the ring systems.

polyketides [9]. Decaketides of similar 'biosynthetic' origin like $\mathbf{2}$ and $\mathbf{3}$ have been described not only from engineered biosynthesis but also from a wild-type strain [10]. Nevertheless $\mathbf{2}$ and $\mathbf{3}$ are the first shunt metabolites with an octaketide backbone isolated from a wild-type strain. The question why nature creates 'shunt metabolites' as those presented here remains open. Maybe this is part of evolutionary processes within the producing strain, which cover deletion or insertion of single genes (or gene functions). As a result $\mathbf{2}$ and $\mathbf{3}$ are related to substances isolated from man-made mutant strains.

\section{Fogacin (1)}

A colourless solid. $[\alpha]_{\mathrm{D}}^{20}+7(c 1, \mathrm{MeOH})$; UV $\lambda_{\max }^{\mathrm{MeOH}} \mathrm{nm}$ (ع) 333 (900), 272 (2550), 222 (4260); $\lambda_{\max }^{0.01 \mathrm{M} \mathrm{HCl}-\mathrm{MeOH}} \mathrm{nm}$ (ع) 331 (1050), 271 (2530), 221 (4390); $\lambda_{\max }^{0.01 \mathrm{M} ~ \mathrm{NaOH}-\mathrm{MeOH}} \mathrm{nm}$ (ع) 333 (1290), 271 (3120), 223 (4660); CD $\lambda_{\text {extreme }}^{\mathrm{MeOH}}(\theta)$ $\mathrm{deg} \cdot \mathrm{cm}^{2} \cdot$ decimole $^{-1} 268 \quad(-4190), 214 \quad(8060) ;$ IR $v_{\max } \mathrm{cm}^{-1} 3428$ (br), 2937, 2354, 1707, 1625, 1370, 1264, 1155,$1085 ;{ }^{1} \mathrm{H}$ NMR $\left(300 \mathrm{MHz}, \mathrm{CD}_{3} \mathrm{OD}\right) \delta 6.86(1 \mathrm{H}, \mathrm{s}, 5-$ $\mathrm{H}), 5.06\left(1 \mathrm{H}, \mathrm{q}, J_{1,3}=6.5 \mathrm{~Hz}, 1-\mathrm{H}\right), 4.81\left(1 \mathrm{H}, \mathrm{dd}, J_{7 \mathrm{a}, \mathrm{b}}=8.0\right.$, $3.5 \mathrm{~Hz}, 6-\mathrm{H}), 4.43(1 \mathrm{H}, \mathrm{m}, 3-\mathrm{H}), 2.89(1 \mathrm{H}, \mathrm{ddd}$, $\left.J_{7 \mathrm{a}, \mathrm{b} ; 8 \mathrm{a}}=17.0,9.0,4.5 \mathrm{~Hz}, 8-\mathrm{H}_{\mathrm{b}}\right), 2.85\left(1 \mathrm{H}, \mathrm{m}, 4-\mathrm{H}_{\mathrm{b}}\right), 2.68$ $\left(1 \mathrm{H}, \mathrm{m}, 4-\mathrm{H}_{\mathrm{a}}\right), 2.65\left(1 \mathrm{H}, \mathrm{ddd}, J_{7 \mathrm{a}, \mathrm{b} ; 8 \mathrm{~b}}=17.5,9.0,4.5 \mathrm{~Hz}, 8-\right.$ $\left.\mathrm{H}_{\mathrm{a}}\right), 2.56\left(2 \mathrm{H}, \mathrm{m}, 11-\mathrm{H}_{2}\right), 2.29\left(1 \mathrm{H}, \mathrm{m}, 7-\mathrm{H}_{\mathrm{b}}\right), 2.10(1 \mathrm{H}$, $\left.\mathrm{m}, 7-\mathrm{H}_{\mathrm{a}}\right), 1.55\left(3 \mathrm{H}, \mathrm{d}, J_{1}=6.5 \mathrm{~Hz} 13-\mathrm{H}_{3}\right) ;{ }^{13} \mathrm{C}-\mathrm{NMR}$ (75.5 MHz, $\left.\mathrm{CD}_{3} \mathrm{OD}\right) \delta 206.1$ (s, C-9), 176.0 (s, C-12), 159.7 (s, C-10), 145.9 (s, C-5a), 144.1 (s, C-4a), 127.8 (s, C-10a), 119.1 (d, C-5), 114.2 (s, C-9a), 69.3 (d, C-1), 68.1 (d, C-6), 65.4 (d, C-3), 42.9 (t, C-11), 35.8 (t, C-8), 35.4 (t, C-4), 32.5 (t, C-7), 19.3 (q, C-13); ESI-MS $m / z 305$ 

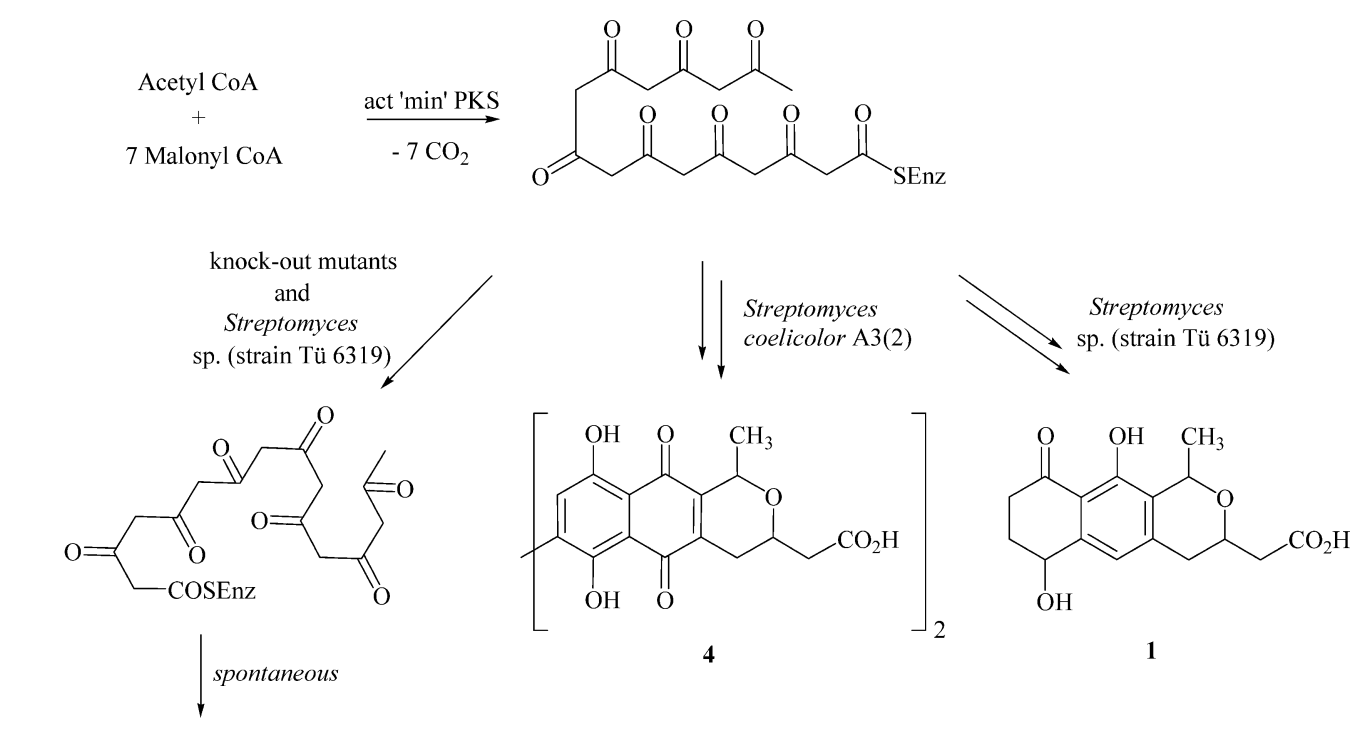<smiles>Cc1cc(O)cc2c1C(=O)CC(O)(Cc1cc(=O)cc(O)o1)O2</smiles>

2

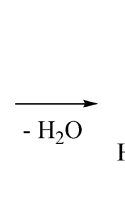

$\overbrace{3}^{C}$

Fig. 3 Putative biosynthesis and folding pattern of fogacin (1), SEK4b (2) and anhydroSEK4b (3) in comparison to actinorhodin (4).

$(\mathrm{M}-\mathrm{H})^{-}$; HRESI-MS $m / z 307.11763\left([\mathrm{M}+\mathrm{H}]^{+}, \mathrm{C}_{16} \mathrm{H}_{19} \mathrm{O}_{6}\right.$ $\left.\delta_{\mathrm{m}} 0.07 \mathrm{mmu}\right)$.

\section{References}

1. Riedlinger J, Tarkka MT, Schrey SD, Hampp R, Kapur M, Fiedler H-P. Auxofuran, a novel metabolite stimulating growth of fly agaric, produced by the mycorrhiza helper bacterium Streptomyces AcH 505. Appl Environ Microbiol (in press)

2. Fiedler H-P. Biosynthetic capacities of actinomycetes. 1. Screening for secondary metabolites by HPLC and UVvisible absorbance spectral libraries. Nat Prod Lett 2: 119-128 (1993)

3. Fu H, Hopwood DA, Khosla C. Engineered biosynthesis of novel polyketides: evidence for temporal, but not regiospecific, control of cyclization of an aromatic polyketide precursor. Chem Biol 1: 205-210 (1994)

4. Petersen F, Zähner H, Metzger JW, Freund S, Hummel R-P. Germicidin, an autoregulative germination inhibitor of Streptomyces viridochromogenes NRRL B-1551. J Antibiot 46: 1126-1134 (1993)

5. Xiang L, Kalaitzis JA, Moore BS. EncM, a versatile enterocin biosynthetic enzyme involved in Favorskii oxidative rearrangement, aldol condensation and heterocycle-forming reactions. PNAS 101: 15609-15614 (2004)

6. Taguchi T, Ebizuka Y, Hopwood DA, Ichinose K. Identification of a novel shunt product produced by a disruptant of the actVI-ORFA gene involved in the biosynthesis of actinorhodin in Streptomyces coelicolor A3(2). Tetrahedron Lett 41: 5253-5256 (2000)

7. Taguchi T, Itou K, Ebizuka Y, Malpartida F, Hopwood DA, Surti CM, Booker-Milburn KI, Stephenson GR, Ichinose K. Chemical characterisation of disruptants of the Streptomyces coelicolor A3(2) actVI genes involved in actinorhodin biosynthesis. J Antibiot 53: 144-152 (2000)

8. Lee TS, Khosla C, Tang Y. Orthogonal protein interactions in spore pigment producing and antibiotic producing polyketide synthases. J Antibiot 58: 663-666 (2005)

9. Shen B, Summers RG, Wendt-Pienkowski E, Hutchinson CR. The Streptomyces glaucescens tcmKL polyketide synthase and $t c m N$ polyketide cyclase gene govern the size and shape of aromatic polyketides. J Am Chem Soc 117: 6811-6821 (1995)

10. Bindseil KU, Hug P, Peter HP, Petersen F, Roggo BE. Balmoralmycin, a new angucyclinone, and two related biosynthetic shunt products containing a novel ring system. J Antibiot 48: 457-461 (1995) 